\title{
PEMAKAIAN PEMBALUT SAAT MENSTRUASI DENGAN KEJADIAN PRURITUS PADA VULVA
}

\author{
Uliyatul Laili ${ }^{1}$, Eka Dewi Crusitasari ${ }^{2}$ \\ 1,2 Universitas Nahdlatul Ulama Surabaya \\ Email: Uliyatul.laili@unusa.ac.id, Dewicrusitasari@gmail.com
}

\begin{abstract}
ABSTRAK
Remaja putri yang mampu menjaga kebersihan vagina saat menstruasi tidak akan mengalami pruritus vulva. Namun kenyataannya, masih banyak remaja yang mengalami pruritus vulva, terutama pada remaja yang berada di lingkungan pondok pesantren. Salah satu penyebab pruritus vulva yaitu adanya dermatitits kontak iritan, rangsangan oleh ektoparasit serta faktor lingkungan yang membuat kulit lembab atau kering. Tujuan penelitian ini adalah untuk menganalisis hubungan frekuensi pemakaian pembalut saat menstruasi dengan kejadian pruritus vulva.

Jenis penelitian yaitu deskriptif analitik dengan desain cross sectional. Populasi seluruh santriwati SMA Al-Furqon pondok pesantren Al-Furqon Driyorejo Gresik, sampel sebanyak 57 orang dengan menggunakan teknik simple random sampling. Instrumen penelitian yang digunakan adalah kuesioner. Analisis data menggunakan uji statistik Chi-Square dengan hasil < a 0,05.

Hasil penelitian didapatkan sebagian besar $(63,2 \%)$ tidak sering mengganti pembalut, sebagian besar $(56,1 \%)$ mengalami pruritus vulva kategori sedang. Berdasarkan hasil uji statistik diperoleh nilai $\rho=0,000<$ a 0,05 berarti $\mathrm{H}_{0}$ di tolak artinya ada hubungan frekuensi pemakaian pembalut saat menstruasi dengan kejadian pruritus vulva.

Semakin sering mengganti pembalut saat menstruasi maka akan menurunkan kejadian pruritus vulva, disarankan bagi wanita untuk sering mengganti pembalut saat menstruasi sehingga mencegah pruritus vulva.
\end{abstract}

\section{Kata Kunci : Frekuensi Pemakaian Pembalut, Pruritus Vulva}

\section{PENDAHULUAN}

Ketika menstruasi kondisi vagina akan semakin lembab, hal ini dikarenakan permukaan kulit pembalut bersentuhan langsung dengan vagina. Pembalut yang mengandung banyak gumpalan darah menjadi tempat yang baik untuk pertumbuhan dan perkembangan jamur dan bakteri. Saat pemakaian, pembalut sering menimbulkan infeksi, iritasi, dan gatal-gatal. Hal berbahaya lain yang dapat disebabkan oleh pembalut adalah ketika digunakan lebih dari empat jam lamanya. Tanpa disadari, pemakaian pembalut terlalu lama dapat menyebabkan infeksi, iritasi, hingga benjolan yang rasanya sangat gatal dan mengganggu. Apabila hal tersebut terjadi, infeksi sekunder dapat segera terjadi seperti kandidiasis, vaginosis bakterial, dan trikomoniasis. Jika hal ini terjadi maka akan membuat keadaan lebih buruk (Tony, 2011). 
Berdasarkan data dari badan kesehatan Dunia (WHO, 2007 dalam Sari dkk, 2012), angka kejadian infeksi saluran reproduksi (ISR) tertinggi di dunia adalah pada usia remaja (35\%-42\%) dan dewasa muda (27\%-33\%). Diantara negara-negara di Asia Tenggara, wanita Indonesia lebih rentan mengalami ISR yang dipicu iklim Indonesia yang panas dan lembab. Jumlah kasus ISR di Jawa Timur seperti candidiasis dan servisitis yang terjadi pada remaja putri sebanyak 86,5\% ditemukan di Surabaya dan Malang. Penyebab tertinggi dari kasus tersebut adalah jamur candida albican sebanyak $77 \%$ yang senang berkembang biak dengan kelembapan tinggi seperti pada saat menstruasi. Hasil riset membuktikan bahwa 5,2 anak-anak remaja putri di 17 provinsi di Indonesia mengalami keluhan yang sering terjadi setelah menstruasi akibat tidak menjaga kebersihannya yaitu pruritus vulva ditandai adanya sensasi gatal pada alat kelamin wanita (Kemenkes RI, 2016).

Pembalut yang terlalu lama didiamkan akan menyebabkan masuknya kuman ke dalam tubuh melalui vagina, lalu merembet ke atas, melewati mulut rahim. Saat kuman tersebut merajalela, dapat menyebabkan peradangan, perekatan lalu menyumbat saluran telur sehingga berakibat kemandulan. Ketika menstruasi semakin banyak darah yang terkena kulit, maka akan semakin besar juga kemungkinan terkena masalah-masalah kulit. Hal itu karena darah merupakan media pertumbuhan bagi bakteri, jamur dan virus. Salah satu yang perlu ditekankan dalam menjaga kebersihan vagina saat menstruasi adalah dengan memperhatikan pemakaian pembalut saat menstruasi. Apabila kita tidak segera mengganti pembalut disaat sedang banyak-banyaknya, hal ini nantinya dapat menimbulkan iritasi dan lama-lama menjadi infeksi. Kulit pada area vagina bersifat asam dengan $\mathrm{pH} 4-4,5$, sementara darah bersifat basa $\mathrm{pH}$ yang dikeluarkan oleh darah ini sifatnya kulit. Ketika sedang menstruasi kulit akan menjadi lebih rentan terhadap iritasi dan bakteri akan lebih tinggi kemungkinannya untuk timbul, salah satu penyebabnya adalah kelembapan (Sari, 2012)

Sehubungan dengan masalah diatas maka diperlukan upaya untuk mensiosialisasikannya yaitu dengan memberikan informasi atau penyuluhan tentang pemeliharaan kebersihan genetalia salah satunya yaitu frekuensi pemakaian pembalut yang ideal saat menstruasi. Dengan pemberian informasi atau penyuluhan ini diharapkan wanita yang sedang mengalami menstruasi dapat melakukan pemeliharaan kebersihan genetalia dan memperhatikan frekuensi pemakaian pembalut saat menstruasi sehingga timbulnya pruritus vulva ini tidak mengarah pada penyakit yang berujung pada keganasan. Berdasarkan latar belakang tersebut maka penulis melakukan penelitian yaitu menganalisis frekuensi pemakaian pembalut saat menstruasi dan mengidentifikasi kejadian pruritus vulva santriwati pondok pesantren Al-Furqon Driyorejo Gresik. 


\section{METODE}

Metode penelitian yang digunakan dalam penelitian ini adalah deskriptif analitik dengan pendekatan cross sectional. Populasi dalam penelitian ini adalah seluruh santriwati SMA Al-Furqon pondok pesantren Al-Furqon Driyorejo Gresik sebanyak 57 orang. Cara pengambilan sampel dengan teknik simple random sampling. Instrumen yang digunakan adalah kuesioner yang diisi oleh responden, kemudian dilakukan uji analisis data dengan chi square.

HASIL

Tabel 1 Distribusi frekuensi responden berdasarkan lama menstruasi

\begin{tabular}{llll}
\hline $\begin{array}{l}\text { No } \\
\text { Menstruasi } \\
\text { (Hari) }\end{array}$ & $\begin{array}{l}\text { Frekuensi } \\
\text { (n) }\end{array}$ & $\begin{array}{l}\text { Presentase } \\
\text { (\%) }\end{array}$ \\
\hline 1. & $1-7$ & 51 & 89,5 \\
$2 . \quad>7$ & 6 & 10,5 \\
\hline Jumlah & $\mathbf{5 7}$ & $\mathbf{1 0 0}$ \\
\hline
\end{tabular}

Sumber: Data Primer, Mei 2019

Berdasarkan tabel 1 menunjukkan bahwa dari 57 responden hampir seluruhnya 51 responden $(89,5 \%)$ lama menstruasinya 1-7 hari.

Tabel 2 Distribusi frekuensi responden berdasarkan siklus menstruasi

\begin{tabular}{|c|c|c|c|}
\hline No & $\begin{array}{c}\text { Siklus } \\
\text { Menstruasi } \\
\text { (Hari) }\end{array}$ & $\begin{array}{l}\text { Frekuensi } \\
\text { (n) }\end{array}$ & $\begin{array}{l}\text { Presentase } \\
(\%)\end{array}$ \\
\hline 1. & $<21$ & 4 & 7,0 \\
\hline 2. & 21-35 & 47 & 82,5 \\
\hline 3. & $>35$ & 6 & 10,5 \\
\hline \multicolumn{2}{|c|}{ Jumlah } & 57 & 100 \\
\hline
\end{tabular}

Berdasarkan tabel 2 menunjukkan bahwa dari 57 responden hampir seluruhnya

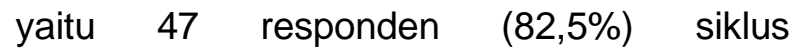
menstruasinya 21-35 hari.
Tabel 3 Distribusi frekuensi responden berdasarkan frekuensi pemakaian pembalut

\begin{tabular}{|c|c|c|}
\hline $\begin{array}{l}\text { No Frekuensi } \\
\text { Pemakaiaan } \\
\text { Pembalut }\end{array}$ & $\begin{array}{l}\text { Frekuensi } \\
\text { (n) }\end{array}$ & $\begin{array}{l}\text { Presentase } \\
(\%)\end{array}$ \\
\hline 1. Tidak Sering & 36 & 63,2 \\
\hline 2. Sering & 21 & 36,8 \\
\hline Jumlah & 57 & 100 \\
\hline
\end{tabular}

Sumber: Data Primer, Mei 2019

Berdasarkan tabel 3 menunjukkan bahwa dari 57 responden sebagian besar 36 responden $(63,2 \%)$ tidak sering mengganti pembalut.

Tabel 4 Distribusi frekuensi responden berdasarkan kejadian pruritus vulva

\begin{tabular}{llll}
\hline No & $\begin{array}{l}\text { Kejadian } \\
\text { Pruritus } \\
\text { Vulva }\end{array}$ & $\begin{array}{l}\text { Frekuensi } \\
\text { (n) }\end{array}$ & $\begin{array}{l}\text { Presentase } \\
\text { (\%) }\end{array}$ \\
\hline 1. & Berat & 0 & 0 \\
2. & Sedang & 32 & 56,1 \\
3. & Ringan & 25 & 43,9 \\
\hline Jumlah & $\mathbf{5 7}$ & $\mathbf{1 0 0}$ \\
\hline Sumber: Data Primer, Mei 2019
\end{tabular}

Sumber: Data Primer, Mei 2019

Pada tabel 4 menunjukkan bahwa dari 57 responden sebagian besar 32 responden $(56,1 \%)$ mengalami pruritis vulva sedang.

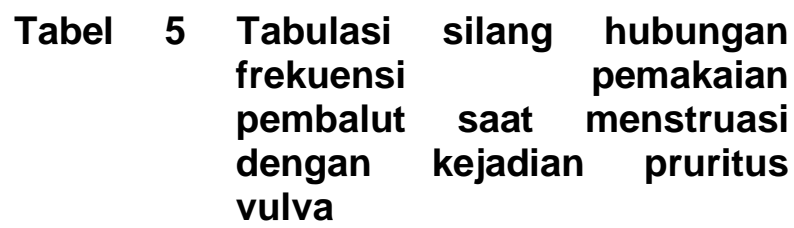

\begin{tabular}{|c|c|c|c|c|}
\hline \multirow[t]{2}{*}{$\overline{\text { No }}$} & \multirow{2}{*}{$\begin{array}{l}\text { Frekuensi } \\
\text { Pemakaiaan } \\
\text { Pembalut }\end{array}$} & \multicolumn{2}{|c|}{$\begin{array}{l}\text { Kejadian } \\
\text { Pruritus Vulva }\end{array}$} & \multirow[t]{2}{*}{$\begin{array}{l}\text { Jumlah } \\
\text { n (\%) }\end{array}$} \\
\hline & & $\begin{array}{l}\text { Ringan } \\
\text { n (\%) }\end{array}$ & $\begin{array}{l}\text { Sedang } \\
\mathrm{n}(\%)\end{array}$ & \\
\hline 1. & Sering & $\begin{array}{l}18 \\
(85,7)\end{array}$ & $3(14,3)$ & $\begin{array}{l}21 \\
(100)\end{array}$ \\
\hline 2. & $\begin{array}{l}\text { Tidak } \\
\text { Sering }\end{array}$ & $\begin{array}{l}7 \\
(19,4)\end{array}$ & $\begin{array}{l}29 \\
(80,6)\end{array}$ & $\begin{array}{l}36 \\
(100)\end{array}$ \\
\hline & Jumlah & $\begin{array}{l}25 \\
(43,9)\end{array}$ & $\begin{array}{l}32 \\
(56,1)\end{array}$ & $\begin{array}{l}57 \\
(100)\end{array}$ \\
\hline
\end{tabular}

Sumber: Data Primer, Mei 2019 
Pada tabel 5 tabulasi silang dapat diketahui dari keseluruhan responden yang berjumlah 57 responden, terdapat 21 responden yang frekuensi pemakaian pembalut saat menstruasi dalam kategori sering mengalami pruritus vulva dalam kategori ringan (85,7\%), dan dari 36 responden yang frekuensi pemakaian pembalut saat menstruasi dalam kategori tidak sering mengalami pruritus vulva dalam kategori sedang $(80,6 \%)$.

Berdasarkan hasil uji Chi-Square program SPSS 16 for windows hubungan frekuensi pemakaian pembalut saat menstruasi dengan kejadian pruritus vulva pada santriwati pondok pesantren Al-Furqon Driyorejo Gresik, didapatkan nilai $\rho(0,000)<$ a $(0,05)$ maka $\mathrm{H}_{0}$ ditolak berarti ada hubungan frekuensi pemakaian pembalut saat menstruasi dengan kejadian pruritus vulva pada santriwati pondok pesantren AlFurqon Driyorejo Gresik.

\section{PEMBAHASAN}

\section{Frekuensi pemakaian pembalut saat menstruasi}

Berdasarkan pengkajian lebih lanjut oleh peneliti ada beberapa faktor yang mempengaruhi responden tidak sering dalam memakai pembalut saat menstruasi, yakni mereka merasa cukup dengan hanya memakai pembalut 1-3 kali sehari, jarang sekali menggunakan pembalut dengan frekuensi 4 kali sehari kecuali dalam keadaan darurat seperti tembus yang dikarenakan penggunaan pembalut tidak tepat atau akibat sangat banyaknya darah yang keluar. Tingginya aktivitas kegiatan sekolah belum lagi aktivitas pondok juga menjadi alasan mereka malas untuk mengganti pembalut. Bahkan ada juga yang mengatakan sayang kalau harus borosboros memakai pembalut. Selain itu, responden belum pernah mendapatkan materi tentang kesehatan reproduksi, besar kemungkinan ini menjadi salah satu alasan mereka belum mengetahui secara pasti berapa frekuensi pemakaian pembalut yang ideal dan pentingnya memperhatikan frekuensi pemakaian pembalut saat menstruasi. Sedangkan untuk responden yang sering dalam pemakaian pembalut saat menstruasi dikarenakan memang mereka terbiasa menggunakan pembalut lebih dari 3 kali sehari, selain merasa lebih nyaman dan percaya diri dalam beraktivitas sepertinya mereka telah menyadari pentingnya menjaga kebersihan organ reproduksi saat menstruasi.

Hasil penelitian ini tidak sesuai dengan pernyataan Elmart (2012), bahwa wanita disarankan mengganti pembalut tiap 4 sampai 6 jam sekali pada saat datang bulan. Minimal 4 kali sehari tanpa harus melihat seberapa banyak darah haid yang keluar. Menstruasi merupakan mekanisme tubuh untuk membuang darah kotor. Pemakaian pembalut tidak boleh lebih dari enam jam dan diganti sesering 
mungkin bila sudah penuh oleh darah. Perempuan perlu mengganti pembalut lebih sering karena aliran darah di vagina lebih banyak. Kebutuhan mengganti pembalut bervariasi pada tiap individu. Secara umum, pembalut perlu diganti setiap empat sampai enam jam sehari, tergantung dari derasnya aliran darah haid. Ketika menstruasi kondisi vagina akan semakin lembab, hal ini diakarenakan permukaan pembalut yang bersentuhan dengan kulit vagina dan pembalut yang megandung banyak gumpalan darah merupakan tempat yang baik bagi pertumbuhan dan perkembangan jamur dan bakteri (Andira, 2010).

Hasil penelitian juga didapatkan bahwa dari 57 responden santriwati pondok pesantren Al-Furqon Driyorejo Gresik hampir seluruhya 47 responden (82,5\%) memiliki siklus menstruasi 21-35 hari.

Menurut peneliti, remaja dengan usia 10 hingga 13 tahun, haidnya belum teratur, dan mengalami siklus haid berubah-ubah dengan jumlah darah haid masih sangat bervariasi dan setelah usia 13 tahun, haidnya akan teratur dan lebih banyak. Penggolongan umur merupakan hal penting karena merukan penjembatan antara usia anak-anak dengan remaja, dimana mulai terjadi perubahan perkembangan (Kusmiran, 2012). Meskipun menstruasi pada remaja tidak teratur, remaja tersebut tidak akan merasa nyeri atau kram saat menstruasi.

Menurut teori dari Prawirohardjo (2011) menyatakan bahwa siklus menstruasi normal berlangsung selama 21-35 hari, dengan lama keluarnya darah haid berlangsung selama 4-7 hari. Ketika seorang wanita mengalami siklus menstruasi yang lebih singkat dari 21 hari, ini mengakibatkan seseorang mengalami perdarahan jumlahnya berlebihan dan sering. Sesuai dengan teori dari Manuaba (2009), menyatakan bahwa jumlah darah haid yang keluar perhari normalnya 60-80 cc perhari, atau tidak lebih dari 5 pembalut yang terisi penuh. Berdasarkan tabel 2 dilihat bahwa dari 57 responden hampir seluruhya 47 responden (82,5\%) memiliki siklus menstruasi 21-35 hari dan perkiraan jumlah darah haid yang dikeluarkan perhari \pm 60-80 cc, oleh sebab itu tidak harus menunggu penuh untuk mengganti pembalut sebab ini akan berpengaruh terhadap kelembapan area vagina.

\section{Kejadian Pruritus Vulva}

Berdasarkan tabel 5 dapat diketahui bahwa dari 57 responden sebagian besar 32 responden $(56,1 \%)$ mengalami pruritus vulva dalam kategori sedang. Hal ini tidak jauh berbeda dengan data penelitian sebelumnya oleh Ismi Sulaikha (2018) yang menunjukkan bahwa dari 40 
responden (57,5\%) mengalami pruritus vulva dalam kategori sedang.

Menurut peneliti, remaja di pondok pesantren Al-Furqon Driyorejo Gresik seluruhnya mengalami pruritus vulva baik dalam kategori sedang maupun ringan. Hal ini terbukti pada kuesioner pruritus vulva nomor satu dan tiga. Kuesioner nomor satu menyatakan gatal-gatal pada daerah kemaluan, dimana gatal-gatal bisa terjadi karena kurangnya personal hygiene saat menstruasi salah satunya yaitu kurang memperhatikan lamanya mengganti pembalut. Sedangkan kuesioner nomor tiga menyatakan keputihan, dimana rasa gatal terus menerus yang disebabkan oleh jamur, bakteri, virus, dan parasit dapat mempengaruhi terjadinya keputihan. Keputihan bisa terjadi karena responden kurang menjaga kebersihan vagina, salah satunya yaitu dalam pemakaian pembalut, jika tidak sering mengganti pembalut ketika menstruasi maka jamur, bakteri, virus, dan parasit akan tumbuh subur yang mengakibatkan timbulnya rasa gatal di vagina.

Menurut Tony (2011) salah satu faktor yang dapat mempengaruhi kejadian pruritus vulva saat menstruasi yaitu lamanya mengganti pembalut. Mengganti pembalut sesering mungkin dapat menghindari dan mengurangi pertumbuhan jamur, bakteri, virus, dan parasit yang berkembang biak pada kondisi yang lembab serta menghindari bakteri masuk ke vagina. Gumpalan darah haid yang ada dipermukaan pembalut menjadi tempat yang sangat baik untuk perkembangan bakteri dan jamur.

\section{Hubungan frekuensi pemakaian pembalut saat menstruasi dengan kejadian pruritus vulva}

Berdasarkan uji Chi-Square program SPSS 16 for windows yang telah dilakukan oleh peneliti untuk mengetahui hubungan frekuensi pemakaian pembalut saat menstruasi dengan kejadian pruritus vulva didapatkan $\rho(0,000)<a(0,05)$ maka $\mathrm{H}_{0}$ ditolak berarti ada hubungan frekuensi pemakaian pembalut saat menstruasi dengan kejadian pruritus vulva pada santriwati pondok pesantren AlFurqon Driyorejo Gresik. Pada table 5 menunjukkan bahwa dari keseluruhan responden yang berjumlah 57 responden, terdapat 21 responden yang frekuensi pemakaian pembalut saat menstruasi dalam kategori sering mengalami pruritus vulva dalam kategori ringan $(85,7 \%)$, dan dari 36 responden yang frekuensi pemakaian pembalut saat menstruasi dalam kategori tidak sering mengalami pruritus vulva dalam kategori sedang (80,6\%).

Dari hasil penelitian banyak santriwati yang mengalami kejadian pruritus vulva dalam kategori sedang, dikarenakan frekuensi pemakaian pembalut yang tidak sering. Karena ketika menstruasi akan terjadi penumpukan 
darah pada pembalut, yang mana hal ini dapat meningkatkan kelembapan pada daerah vagina yang nantinya akan memicu terjadinya pruritus vulva. Hal Ini menunjukkan pentingnya memperhatikan frekuensi pemakaian pembalut saat menstruasi. Penderita yang mengalami pruritus vulva akan merasa terganggu karena ketidaknyamanan dalam beraktivitas, dan jika pruritus vulva berlangsung lama, dapat berpengaruh besar terhadap kondisi penderita, sebab penderita akan merasa malu, sedih, bahkan rendah diri.

Menurut (Tony, 2011) salah satu faktor yang dapat mempengaruhi kejadian pruritus vulva saat menstruasi yaitu lamanya mengganti pembalut. Elmart (2012) mengemukakan untuk menjaga kebersihan dalam melakukan perawatan sistem reproduksi, wanita disarankan mengganti pembalut minimal 4 kali sehari tanpa melihat seberapa banyak darah haid yang keluar. Tetapi tidak dipungkiri, biasanya pada hari-hari terakhir menstruasi, banyak diantara kita yang mearasa sayang untuk mengganti pembalut dengan frekuensi minimal 4 kali sehari, apalagi darah haid tinggal sedikit. Maka alternatifnya diperbolehkan tidak mengganti pembalut di dua hari terakhir menstruasi, sebab pada hari-hari tersebut biasanya yang keluar hanya berupa flekflek kecoklatan, yang perlu dilakukan adalah mengganti celana dalam sesering mungkin, hal ini dilakukan agar kondisi organ intim tetap terjaga kelembapannya. Pembalut juga harus sesering mungkin diganti apabila sudah penuh oleh darah menstruasi. Durasi waktu 6 jam menjadi batas maksimal pasukan organisme yang ikut aliran haid untuk berdiam diri. Pemakaian pembalut tidak boleh dipakai lebih dari 6 jam dikarenakan dalam 6 jam kondisi organ intim wanita mengalami kelembapan oleh darah yang keluar dan tertampung di dalam pembalut. Organ reproduksi merupakan daerah tertutup dan berlipat, sehingga lebih mudah untuk berkeringat, lembab dan kotor. Perilaku yang buruk dalam menjaga kebersihan genetalia saat menstruasi dapat menjadi pencetus timbulnya infeksi (Fufut, 2012).

\section{KESIMPULAN}

Dari hasil penelitian yang dilakukan peneliti, maka peneliti menyimpulkan bahwa terdapat hubungan antara frekuensi pemaikan pembalut dengan kejadian pruritus vulva.

\section{DAFTAR PUSTAKA}

Andira, Dita. 2010. Seluk-Beluk Kesehatan Reproduksi Wanita. Jogjakarta: A Plus Book

Elmart, F. 2012. Mahir Menjaga Organ Intim Wanita. Solo: Tinta Medina.

Fufut, Indah. 2012. Kejadian Pruritus Vulvae Saat Menstruasi Pada Remaja Putri. Surabaya: FKM Unair

Ismi, Sulaikha. 2018. Hubungan Personal Hygiene Saat Menstruasi Dengan Kejadian Pruritus Vulvae Pada Remaja (Studi di SMP Pondok Darul Muttaqin Jombang). Skripsi. 
Jombang: Sekolah Tinggi IImu Kesehatan Insan Cendekia Medika

Kemenkes RI. 2017. Profil Kesehatan Indonesia 2016. Keputusan Menteri kesehatan Republik Indonesia. Jakarta

Kusmiran, E. 2011. Kesehatan Reproduksi Remaja dan Wanita. Jogjakarta: Salemba Medika.

Manuaba, I. B. G. (2009). Memahami kesehatan reproduksi wanita (2 ed.). Jakarta: EGC.

Sari, Indah Puspita dkk. 2012. Pengaruh Pendidikan Kesehatan Tentang Menstruasi Terhadap Perubahan Perilaku Menstrual Hygiene Remaja Putri Untuk Pencegahan Infeksi Saluran Reproduksi (ISR).

Sarwono, Prawiroharjo. 2011. IImu Kebidanan. Edisi III. Jakarta: PT Bina Pustaka. Pg 103-107

Tony, Djajakusumah. 2011. Penatalaksanaan Pruritus Anogenital. Surabaya 